\title{
KONSUMSI PANGAN DAN GIZI SERTA SKOR POLA PANGAN HARAPAN (PPH) PADA ANAK USIA 2-6 TAHUN DI INDONESIA
}

\author{
(Food and Nutrients Intake and Desirable Dietary Pattern Score \\ of Indonesian Children Aged 2-6 Years) \\ Teguh Jati Prasetyo ${ }^{1^{*}}$, Hardinsyah ${ }^{1}$, dan Tiurma Sinaga ${ }^{1}$ \\ 'Departemen Gizi Masyarakat, Fakultas Ekologi Manusia, Institut Pertanian Bogor, 16680
}

\begin{abstract}
This study aimed to assess food and nutrients intake, Nutrient Dietary Quality (NDQ), and Desirable Dietary Pattern (DDP) score of children aged 2-6 years. This study was carried out through analyzing a consumption data set of the National Basic Health Research (Riskesdas) 2010 were collected using 24 hour recall method. Total number 16675 of children aged 2-6 years. The results showed that most children eat cereals (99.4\%) and least eat oily seeds (1.6\%). The children had deficiency of energy, fats, and water. They also had deficiency of calcium, vitamin $A$, vitamin $B 9$, and vitamin $C$. The mean DDP score of the children was $67.1 \pm 12.9$. The mean NDQ of the children was 62.4 17 .1. Correlation between DDP score and each of NDQ was found 0.578-0.621 that showed moderate validity result.
\end{abstract}

Keywords: children aged 2-6 years, desirable dietary pattern, food consumption, nutritional dietary quality

\begin{abstract}
ABSTRAK
Penelitian ini bertujuan untuk menilai konsumsi pangan, mutu gizi konsumsi pangan (MGP), skor pola pangan harapan (PPH), dan korelasi antara skor PPH dan MGP anak usia 2-6 tahun. Penelitian ini dilakukan dengan menganalisis data konsumsi Riset Kesehatan Dasar (Riskesdas) 2010 yang dikumpulkan menggunakan metode recall 24 jam. Jumlah anak usia 2-6 tahun sebanyak 24447 anak yang berasal dari 33 provinsi di Indonesia. Setelah melalui kriteria inklusi dan eksklusi, subjek akhir untuk penelitian ini sebanyak 16675 anak. Hasil penelitian menunjukkan bahwa sebagian besar anak mengonsumsi padi-padian (99.4\%) dan paling sedikit mengonsumsi buah/biji berminyak (1.6\%). Anak mengalami defisit zat gizi makro lemak, energi, dan air serta defisit zat gizi mikro berupa kalsium, vitamin A, vitamin B9, dan vitamin C. Anak memiliki rata-rata skor PPH 67.1 \pm 12.9. Rata-rata MGP anak adalah $62.4 \pm 17.1$. Korelasi antara skor PPH dan setiap MGP sebesar $0.578-$ 0.621 yang menunjukkan hasil validitas sedang.
\end{abstract}

Kata kunci: anak usia 2-6 tahun, konsumsi pangan, mutu gizi konsumsi pangan, pola pangan harapan

"Korespondensi: Departemen Gizi Masyarakat, Fakultas Ekologi Manusia (FEMA), Institut Pertanian Bogor, Bogor 16680. Email: teguhjatiprasetyo@gmail.com 


\section{PENDAHULUAN}

Pedoman pola konsumsi pangan dalam rangka promosi kesehatan dan pencegahan penyakit sering kali memiliki peran penting dalam penentuan kebijakan dan edukasi kepada masyarakat tentang pemilihan pangan yang sehat (Willet \& McCullough 2008). Food and Agriculture Organization-Regional Office for Asia and the Pasific (FAO-RAPA) mendefinisikan PPH sebagai komposisi dari kelompok-kelompok pangan utama yang disiapkan untuk dikonsumsi sebagai makanan untuk memenuhi kebutuhan kalori dan akan memberikan zat gizi dalam jumlah yang mencukupi. PPH pertama kali diperkenalkan oleh FAO-RAPA pada tahun 1988 yang kemudian dikembangkan oleh Departemen Pertanian (Deptan) Republik Indonesia melalui workshop yang diselenggarakan Deptan bekerja sama dengan FAO. Tujuan utama penyusunan PPH adalah untuk membuat rasionalisasi pola konsumsi pangan yang dianjurkan yang terdiri dari kombinasi aneka ragam pangan untuk memenuhi kebutuhan gizi dan sesuai cita rasa. Untuk pertama kali PPH kawasan Asia Pasifik dikembangkan berdasarkan data pola pangan (pola ketersediaan pangan) dari neraca bahan makanan (NBM). Hal ini dilakukan karena data inilah yang tersedia secara berkala setiap tahun. Saat ini PPH digunakan untuk mengetahui kondisi kualitas konsumsi pangan rumah tangga, salah satunya dengan menggunakan data Survei Sosial Ekonomi Nasional (SUSENAS) (Hardinsyah et al. 2001).

Dengan pendekatan PPH, keadaan perencanaan penyediaan dan konsumsi penduduk diharapkan dapat memenuhi tidak hanya kecukupan gizi, tetapi juga mempertimbangkan keseimbangan gizi didukung oleh cita rasa, daya cerna, daya terima masyarakat, dan kemampuan daya beli. Ada enam kelompok zat gizi yang penting diperlukan oleh tubuh yaitu protein, lemak, karbohidrat, air, vitamin, dan mineral. Dari beberapa zat gizi tersebut, tubuh akan memperoleh energi sehingga manusia mampu mempertahankan kerja alat-alat tubuh dan melakukan kegiatan fisik sehari-hari. Sejumlah golongan bahan makanan yang tersusun secara seimbang akan mampu memenuhi kebutuhan zat gizi. Golongan pangan tersebut mencakup padi-padian, umbiumbian, pangan hewani, minyak dan lemak, buah/ biji berminyak, kacang-kacangan, gula, sayur dan buah, dan lain-lain (Kantor Menteri Negara Urusan Pangan dalam Hardinsyah et al. 2001). Oleh karena itu, bahan pangan dikelompokkan menjadi sembilan golongan pangan tersebut dalam menentukan PPH. Hal ini lebih sederhana tanpa menghitung semua zat gizi, cukup energi dari sembilan kelompok pangan, dapat menghasilkan satu skor atau indeks (Hardinsyah et al. 2001).

Selama ini perhitungan skor PPH menggunakan data ketersediaan pangan NBM dan konsumsi rumah tangga SUSENAS (BPS), belum pernah dilakukan untuk penilaian mutu konsumsi pangan individu. Penilaian konsumsi gizi individu dilakukan dengan menghitung tingkat kecukupan dari setiap zat gizi. Cara ini lebih rumit karena perlu menghitung setiap zat gizi dan tidak dapat diinterpretasikan berupa satu indeks atau skor. Oleh karena itu, penelitian ini dilakukan untuk menguji apakah sistem skor PPH dapat digunakan pada individu, khususnya anak usia 2-6 tahun. Penelitian ini juga digunakan untuk menguji apakah ada korelasi antara PPH dan mutu gizi konsumsi pangan pada usia tersebut. Hal ini penting dilakukan karena anak pada masa ini mengalami pertumbuhan fisik dan perkembangan otak. Selama masa ini anak memperoleh keterampilan yang memungkinkannya untuk makan secara bebas dan mengembangkan kesukaan makannya sendiri. Selain itu perkembangan keterampilan otot membuat aktivitas fisiknya meningkat. Dengan demikian perlu ditunjang dengan pemberian makanan (zatzat gizi) yang tepat dan memadai serta seimbang agar kebutuhan gizinya dapat terpenuhi.

Tujuan dari penelitian ini adalah untuk menilai konsumsi pangan, mutu gizi konsumsi pangan dan skor pola pangan harapan (PPH) pada anak usia 2-6 tahun di Indonesia.

\section{METODE}

\section{Desain, Tempat, dan Waktu Penelitian}

Penelitian ini dilakukan dengan mengolah data sekunder dari hasil penelitian Riset Kesehatan Dasar (Riskesdas) 2010 dengan desain cross sectional study. Pengumpulan data Riskesdas 2010 dilakukan di beberapa daerah di Indonesia dari bulan Juni-Agustus 2010. Proses perencanaan, pengolahan, analisis, dan interpretasi data untuk penelitian ini dilakukan pada bulan Maret-Agustus 2013 di Kampus Institut Pertanian Bogor, Darmaga, Bogor, Jawa Barat.

\section{Jumlah dan Cara Pengambilan Subjek}

Penelitian ini menggunakan subjek yang berasal dari data Riskesdas 2010 yang diambil dari rumah tangga mewakili 33 provinsi di Indonesia. Proses pemilihan rumah tangga dilakukan Badan Pusat Statistik (BPS) dengan two stage sampling yaitu pemilihan subjek dengan dua tahap. Kriteria subjek yang digunakan dalam penelitian ini adalah subjek berusia 2-6 tahun dalam kondisi sehat, dan konsumsi harian normal (tidak puasa, diet, sakit). Total subjek dalam penelitian ini sebanyak 16675 anak usia 2-6 tahun dengan jumlah anak laki-laki sebanyak 8403 dan anak perempuan sebanyak 8272 .

\section{Jenis dan Cara Pengumpulan Data}

Penelitian ini seluruhnya menggunakan data sekunder yang diperoleh dalam bentuk electronic 
file berupa entry data dan hasil pengolahan Riskesdas 2010. Data yang diambil diantaranya adalah karakteristik individu, karakteristik keluarga, antropometri, dan konsumsi pangan. Karakteristik individu terdiri atas asal daerah, usia, jenis kelamin, dan pendidikan. Data karakteristik keluarga terdiri dari pendidikan dan pekerjaan ayah dan ibu. Data antropometri berupa data berat badan dan tinggi badan. Data konsumsi pangan terdiri atas data jumlah pangan beserta data jenis pangan. Selain itu diambil juga data mengenai status ekonomi dan asupan energi dan zat gizi.

\section{Pengolahan dan Analisis Data}

Berdasarkan Riskesdas 2010 diperoleh data sekunder mengenai wilayah tempat tinggal, pen- didikan dan pekerjaan orangtua, serta status ekonomi dari subjek. Data mengenai karakteristik Individu dan keluarga diolah dengan statistik deskriptif. Perhitungan kebutuhan energi menggunakan rumus dari Institute of Medicine (IOM) tahun 2002 dalam Mahan \& Escoot-stump (2008) yang didasarkan pada oxford equation (Tabel 1).

Formula estimasi Angka Kecukupan Protein (AKP) dalam WNPG 2012 digunakan untuk perhitungan kebutuhan protein sesuai dengan kelompok umur dan jenis kelamin.

$$
\mathrm{KP}=\mathrm{AKP} \times \mathrm{faktor} \text { koreksi mutu protein }
$$

Keterangan: KP: Kebutuhan protein; AKP = Angka kecukupan protein $(1.2 \mathrm{~g} / \mathrm{kgBB} / \mathrm{hari}$ usia $1-3$ tahun; $1.0 \mathrm{~g} / \mathrm{kgBB} /$ hari usia 4-6 tahun ); Faktor koreksi mutu protein $=1.5$

Tabel 1. Perhitungan Kebutuhan Energi menurut Usia dan Jenis Kelamin

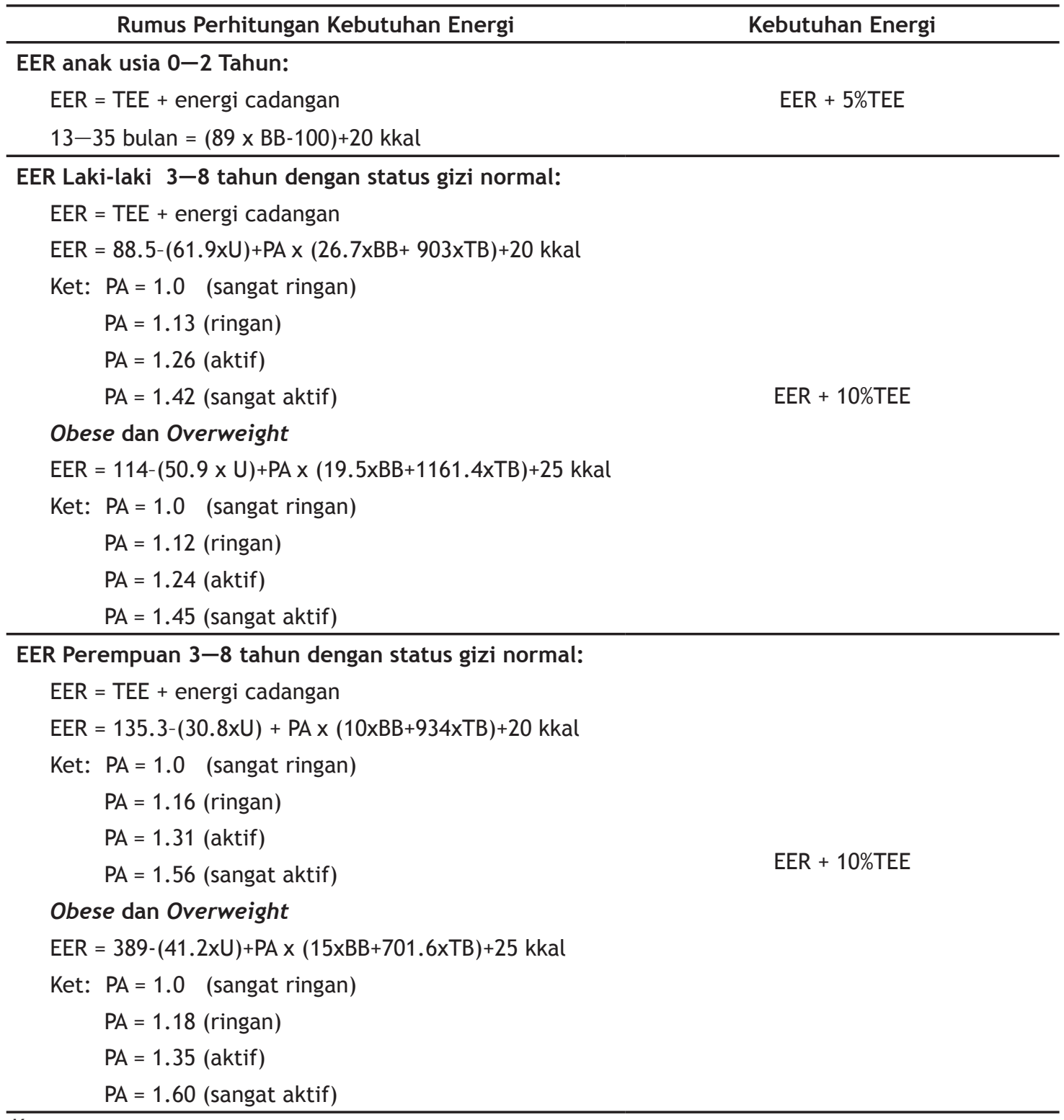

\section{Keterangan:}

$\mathrm{U}=$ umur (tahun), BB=berat badan $(\mathrm{kg}), \mathrm{TB}=\operatorname{tinggi}$ badan $(\mathrm{m})$; EER=estimasi kebutuhan energi (kkal); $\mathrm{TEE}=$ total pengeluaran energi (kkal); PA=koefisien aktivitas fisik 
Perhitungan data kebutuhan lemak didasarkan pada perbandingan komposisi energi dari karbohidrat, protein, dan lemak. Kebutuhan air dihitung berdasarkan Angka Kecukupan Gizi (AKG) 2013. Kebutuhan zat gizi mikro dihitung berdasarkan AKG sesuai dengan usia dan jenis kelamin. Adapun zat gizi mikro yang dihitung adalah vitamin A, vitamin B1, vitamin B9, vitamin B12, vitamin C, kalsium, fosfor, besi, dan seng.

Perhitungan asupan zat gizi dilakukan dengan menggunakan data konsumsi pangan berupa jenis dan jumlah makanan dalam gram/URT yang dikonversi ke dalam nilai zat gizi dengan menggunakan daftar komposisi bahan makanan (DKBM). Perhitungan tersebut akan menghasilkan kandungan gizi masingmasing bahan pangan dari pangan yang dikonsumsi oleh subjek. Setelah perhitungan kandungan zat gizi dilakukan, dilanjutkan dengan menghitung tingkat kecukupan masing-masing zat gizi.

Berdasarkan perhitungan tingkat kecukupan zat gizi, dapat diperoleh nilai mutu gizi konsumsi pangan (MGP) dari seluruh zat gizi yang dikonsumsi oleh subjek. Penilaian MGP dilakukan dengan menganalisis kandungan gizi makanan yang dikonsumsi dibandingkan dengan kecukupan gizi yang dianjurkan dan dinyatakan dalam persen. Perhitungan MGP dibedakan menjadi 3 jenis yaitu MGP4, MGP10, dan MGP14. MGP4 meliputi energi, lemak, protein, dan karbohidrat. MGP10 meliputi energi, protein, karbohidrat, lemak, vitamin A, vitamin B1, vitamin C, kalsium, fosfor, dan besi. MGP14 meliputi energi, protein, karbohidrat, lemak, air, vitamin A, vitamin B1, vitamin B9, vitamin B12, vitamin C, kalsium, fosfor, besi, dan seng. Ada empat kategori yang digunakan untuk mengelompokkan MGP yaitu sangat kurang $(<55)$, kurang (55-69), cukup (70-84), dan baik ( $\geq 85$ ) (Hardinsyah 1996).

Metode PPH dapat menghasilkan satu skor yang mencerminkan mutu dan keragaman pangan secara keseluruhan. Selain itu dapat diketahui pula kesenjangan antara konsumsi dan kebutuhan pangan (energi) pada masing-masing kelompok pangan. Ada sembilan kelompok pangan yang digunakan untuk menghitung PPH yaitu padi-padian, umbi-umbian, pangan hewani, minyak dan lemak, buah/biji berminyak, kacang-kacangan, gula, buah dan sayur serta lain-lain. Pangan yang dikonsumsi rumah tangga terdapat dalam berbagai bentuk dan jenis dengan satuan yang berbeda, sehingga dilakukan konversi ke dalam satuan dan jenis komoditas yang sama. Selanjutnya dihitung asupan energi menurut kelompok pangan per kapita/hari. Setelah itu dilanjutkan dengan menghitung skor PPH. PPH hasil perhitungan selanjutnya digolongkan berdasarkan empat kategori yaitu sangat kurang $(<55)$, kurang (55-69), cukup (70-84), dan baik ( $\geq 85)$.

Hasil pengolahan data yang dianalisis secara statistik disajikan dalam bentuk tabel. Anali- sis statistik menggunakan uji normalitas, uji beda-t (independent samples $t$-test) dan uji korelasi Rank Spearman. Perbandingan antar peubah pada penelitian ini yang terdiri atas mutu gizi konsumsi pangan dan skor pola pangan harapan dianalisis dengan Uji beda-t (independent samples $t$-test) berdasarkan jenis kelamin dan kelompok usia. Uji korelasi Rank Spearman digunakan untuk mengetahui hubungan antara skor PPH dengan MGP dan tingkat kecukupan gizi.

\section{HASIL DAN PEMBAHASAN}

\section{Konsumsi Pangan}

Konsumsi pangan anak usia 2-6 tahun berasal dari sembilan kelompok pangan yang terdiri dari padi-padian, umbi-umbian, pangan hewani, minyak dan lemak, buah/biji berminyak, kacang-kacangan, gula, sayur dan buah, dan lain-lain. Rata-rata konsumsi pangan anak usia 2-6 tahun sebagian besar berasal dari kelompok pangan lain-lain sebanyak $658.7 \pm 115.8$ g. Kelompok pangan yang paling sedikit dikonsumsi anak usia 2-6 tahun adalah minyak dan lemak dengan rata-rata konsumsi sebanyak 0.4 7.9 g (Tabel 2).

Berdasarkan hasil perhitungan tingkat partisipasi konsumsi pangan dari sembilan kelompok pangan diketahui bahwa kelompok pangan yang paling banyak partisipasi konsumsinya adalah padi-padian (99.4\%). Kelompok pangan padi-padian terdiri atas beras dan olahannya, jagung dan olahannya serta gandum dan olahannya. Beras memiliki tingkat partisipasi yang paling tinggi dikonsumsi dibandingkan dengan jagung dan gandum. Hasil ini sejalan dengan penelitian yang dilakukan oleh Apriani dan Baliwati (2011) dimana konsumsi pangan sumber karbohidrat didominasi oleh beras. Hasil ini pun sejalan dengan penelitian yang dilakukan oleh Mauludyani et al. (2008) yang menunjukkan hasil bahwa tingkat partisipasi konsumsi beras mendekati $100 \%$ yaitu $97.05 \%$. Penelitian Steyn et al. (2006) yang dilakukan terhadap anak usia 1-8 tahun juga menunjukkan tingkat partisipasi konsumsi padi-padian mencapai 99.6\%. Partisipasi konsumsi pangan paling rendah terdapat pada kelompok pangan buah/biji berminyak (1.6\%). Secara keseluruhan tingkat partisipasi pangan dari yang paling tinggi ke rendah adalah padi-padian (99.4\%), lain-lain (95.5\%), pangan hewani $(83.6 \%)$, sayur dan buah $(64.0 \%)$, umbi-umbian (38.3\%), kacang-kacangan (31.0\%), gula (19.8\%), minyak dan lemak (2.8\%) dan buah/biji berminyak $(1.6 \%)$.

\section{Asupan Zat Gizi dan Tingkat Kecukupan Zat Gizi}

Asupan masing-masing zat gizi dihitung berdasarkan kandungan zat gizi dari 9 kelompok pangan yang dikonsumsi anak usia 2-6 tahun. Hasil perhitungan tersebut dibandingkan dengan kebutuhan 
Tabel 2. Rata-rata, Standar Deviasi (Median) dan Tingkat Partisipasi Konsumsi Pangan Anak menurut Jenis Kelamin, Usia dan Kelompok Pangan

\begin{tabular}{|c|c|c|c|c|c|}
\hline \multirow{3}{*}{$\begin{array}{l}\text { Kelompok } \\
\text { Pangan (g) }\end{array}$} & \multicolumn{2}{|c|}{ Laki-laki } & \multicolumn{2}{|c|}{ Perempuan } & \multirow{3}{*}{ Total } \\
\hline & $2-3$ tahun & 4-6 tahun & $2-3$ tahun & 4-6 tahun & \\
\hline & \multicolumn{4}{|c|}{ Mean $\pm \mathrm{SD}(\mathrm{med}) \%$} & \\
\hline $\begin{array}{l}\text { Padi- } \\
\text { padian }\end{array}$ & $333.1 \pm 62.7(100.0) 99.2$ & $400.3 \pm 70.1(100.0) 99.4$ & $323.3 \pm 60.3(100.0) 99.5$ & $393.9 \pm 70.8(100) 99.3$ & $372.8 \pm 68.1(100.0) 99.4$ \\
\hline $\begin{array}{l}\text { Umbi- } \\
\text { umbian }\end{array}$ & $18.7 \pm 29.8(20.0) 37.3$ & $22.8 \pm 39.1(25.0) 39.6$ & $16.5 \pm 28.7(20.0) 34.1$ & $22.3 \pm 36.6(25.0) 40.0$ & $20.8 \pm 35.3(25.0) 38.3$ \\
\hline $\begin{array}{l}\text { Pangan } \\
\text { hewani }\end{array}$ & $106.3 \pm 37.6(30.0) 85.2$ & $98.2 \pm 31.7(50.0) 83.0$ & $104.4 \pm 37.2(30.0) 84.9$ & $94.2 \pm 32.3(50.0) 82.6$ & $99.4 \pm 34.3(40.0) 83.6$ \\
\hline $\begin{array}{l}\text { Minyak \& } \\
\text { lemak }\end{array}$ & $0.4 \pm 8.3(5.0) 2.8$ & $0.4 \pm 8.4(5.0) 2.7$ & $0.3 \pm 7.3(5.0) 2.5$ & $0.4 \pm 7.5(5.0) 3.1$ & $0.4 \pm 7.9(5.0) 2.8$ \\
\hline $\begin{array}{l}\text { Buah/biji } \\
\text { berminyak }\end{array}$ & $1.1 \pm 112.6(20.0) 1.2$ & $2.0 \pm 121.6(25.0) 1.9$ & $0.9 \pm 88.5(20.0) 1.3$ & $1.1 \pm 90.6(20) 1.7$ & $1.3 \pm 106.6(20) 1.6$ \\
\hline $\begin{array}{l}\text { Kacang- } \\
\text { kacangan }\end{array}$ & $17.4 \pm 25.4(25.0) 28.2$ & $22.9 \pm 26.7(30.0) 31.6$ & $19.3 \pm 32.7(25.0) 29.8$ & $23.1 \pm 26.7(30.0) 32.6$ & $21.3 \pm 27.6(30.0) 31.0$ \\
\hline Gula & $22.5 \pm 89.0(100.0) 17.4$ & $29.4 \pm 85.6$ (200) 20.7 & $21.8 \pm 88.2(100.0) 17.7$ & $30.1 \pm 87.7$ (200) 21.4 & $27.1 \pm 87.8(200) 19.8$ \\
\hline $\begin{array}{l}\text { Sayur \& } \\
\text { buah }\end{array}$ & $60.2 \pm 36.2(50.0) 60.8$ & $71.6 \pm 40.1(50.0) 64.8$ & $58.2 \pm 34.4(50) 62.5$ & $72.3 \pm 42.9(50) 65.8$ & $67.5 \pm 39.6(50) 64.0$ \\
\hline Lain-lain & $624.3 \pm 114.7(200) 93.1$ & $678.9 \pm 117.2(200) 96.7$ & $609.1 \pm 113.0(200) 93.1$ & $684.0 \pm 116.3(200) 96.8$ & $658.7 \pm 115.8(200) 95.5$ \\
\hline
\end{tabular}

Tabel 3. Rata-Rata, Standar Deviasi, dan Median Asupan Gizi Anak 2-6 Tahun menurut Jenis Kelamin dan Kelompok Usia

\begin{tabular}{|c|c|c|c|c|c|}
\hline \multirow{3}{*}{ Zat Gizi } & \multicolumn{2}{|c|}{ Laki-laki } & \multicolumn{2}{|c|}{ Perempuan } & \multirow{3}{*}{ Total } \\
\hline & $2-3$ tahun & 4-6 tahun & $2-3$ tahun & $4-6$ tahun & \\
\hline & \multicolumn{4}{|c|}{ Mean $\pm \mathrm{SD}($ med $)$} & \\
\hline Energi (kkal) & $1066.8 \pm 106.4(67.2)$ & $1223.2 \pm 124.9(67.2)$ & $1037.3 \pm 103.9(67.2)$ & $1200.0 \pm 123.4(67.2)$ & $1155.5 \pm 118.0(67.2)$ \\
\hline Protein (g) & $31.2 \pm 4 .(1.6)$ & $35.7 \pm 5.1(2.1)$ & $30.5 \pm 4.4(1.6)$ & $35.2 \pm 5.2(1.9)$ & $33.8 \pm 4.9(1.8)$ \\
\hline Lemak (g) & $26.0 \pm 4.2(0.2)$ & $28.4 \pm 4.8(0.2)$ & $25.3 \pm 4.1(0.2)$ & $28.0 \pm 4.8(0.2)$ & $27.3 \pm 27.3(0.2)$ \\
\hline Karbohidrat (g) & $183.6 \pm 24.9(4.8)$ & $213.9 \pm 29.5(3.8)$ & $178.4 \pm 24.4(4.5)$ & $210.1 \pm 29.1(3.8)$ & $201.1 \pm 27.8(4.2)$ \\
\hline Air $(\mathrm{mL})$ & $920.5 \pm 101.9(37.2)$ & $1024.104 .2(50.2)$ & $898.8 \pm 100.7(37.1)$ & $1027.2 \pm 105.1(49.5)$ & $985.1 \pm 103.6(45.6)$ \\
\hline Vitamin A $(\mu \mathrm{g})$ & $303.9 \pm 67.8(0.0)$ & $263.8 \pm 71.7(0.0)$ & $287.3 \pm 65.8(0.0)$ & $261.0 \pm 71.6(0.0)$ & $274.2 \pm 70.0(0.0)$ \\
\hline Vitamin B1 (mg) & $0.6 \pm 0.1(0.0)$ & $0.7 \pm 0.2(0.0)$ & $0.6 \pm 0.1(0.0)$ & $0.7 \pm 0.2(0.0)$ & $0.7 \pm 0.2(0.0)$ \\
\hline Vitamin B9 $(\mu \mathrm{g})$ & $81.6 \pm 12.8(2.0)$ & $76.8 \pm 12.2(2.0)$ & $80.0 \pm 12.9(2.0)$ & $75.7 \pm 12.3(2.0)$ & $77.8 \pm 12.5(2.0)$ \\
\hline Vitamin B12 $(\mu \mathrm{g})$ & $1.3 \pm 0.3(0.0)$ & $1.4 \pm 0.3(0.0)$ & $1.3 \pm 0.3(0.0)$ & $1.4 \pm 0.3(0.0)$ & $1.3 \pm 0.3(0.0)$ \\
\hline Vitamin C (mg) & $19.0 \pm 5.1(0.0)$ & $15.3 \pm 5.1(0.0)$ & $18.7 \pm 5.2(0.0)$ & $14.8 \pm 4.8(0.0)$ & $16.4 \pm 5.0(0.0)$ \\
\hline Kalsium (mg) & $433.9 \pm 144.6(5.0)$ & $433.3 \pm 162.2(5.0)$ & $418.2 \pm 142.8(5.0)$ & $429.2 \pm 164.0(5.0)$ & $429.4 \pm 156.6(5.0)$ \\
\hline Fosfor (mg) & $427.6 \pm 69.6(16.6)$ & $448.9 \pm 78.0(17.0)$ & $415.7 \pm 70.6(16.5)$ & $436.1 \pm 77.5(16.5)$ & $435.2 \pm 75.1(16.5)$ \\
\hline Besi (mg) & $8.7 \pm 2.3(0.3)$ & $9.8 \pm 2.7(0.3)$ & $8.4 \pm 2.3(0.3)$ & $9.8 \pm 2.7(0.3)$ & $9.4 \pm 2.6(0.3)$ \\
\hline Seng (mg) & $3.7 \pm 0.5(0.2)$ & $3.6 \pm 0.4(0.2)$ & $3.6 \pm 0.5(0.2)$ & $3.5 \pm 0.4(0.2)$ & $3.6 \pm 0.4(0.2)$ \\
\hline
\end{tabular}

zat gizi sesuai dengan usia dan jenis kelamin untuk mengetahui tingkat pemenuhan kebutuhan (tingkat konsumsi) zat gizi. Secara keseluruhan asupan zat gizi anak laki-laki usia 2-3 tahun lebih besar dibandingkan dengan perempuan. Asupan zat gizi anak laki-laki usia 4-6 tahun juga lebih besar dibandingkan dengan perempuan kecuali pada asupan air. Ratarata konsumsi anak usia 2-6 tahun menurut jenis kelamin dan kelompok usia disajikan pada Tabel 3.

Secara keseluruhan anak usia 2-6 tahun memiliki tingkat pemenuhan kebutuhan lemak, energi, dan air dibawah 90\%. Kemudian tingkat pemenuhan kebutuhan karbohidrat berada pada rentang $90-110 \%$ dan protein diatas $120 \%$. Hal ini menunjukkan bahwa anak usia 2-6 tahun mengalami defisit zat gizi makro berupa lemak, energi, dan air. Rendahnya pemenuhan energi ini sejalan dengan penelitian yang dilakukan oleh Riyadi dan Sukandar (2009) pada anak balita. Penelitian tersebut menunjukkan tingkat pemenuhan energi masih dibawah $70 \%$ lebih rendah daripada hasil penelitian ini. Tingkat pemenuhan kalsium, vitamin A, vitamin B9, dan vitamin C anak usia 2-6 tahun kurang dari $65 \%$ sedangkan tingkat pemenuhan fosfor, besi, seng, vitamin B, dan vitamin B12 sudah lebih dari $65 \%$. Hasil tersebut menunjukkan bahwa anak usia 
2-6 tahun mengalami defisit zat gizi mikro berupa kalsium, vitamin A, vitamin B9, dan vitamin C. Hasil penelitian menunjukkan bahwa tingkat pemenuhan vitamin $\mathrm{C}$ paling rendah dibandingkan dengan zat gizi lain (Tabel 4). Hasil ini sejalan dengan penelitian yang dilakukan oleh Riyadi dan Sukandar (2009) pada balita. Penelitian tersebut menduga bahwa vitamin $\mathrm{C}$ merupakan vitamin yang paling sulit dipenuhi oleh anak-anak.

\section{Mutu Gizi Pangan dan Skor Pola Pangan Harapan}

Perhitungan mutu gizi konsumsi pangan didasarkan tingkat pemenuhan kebutuhan gizi ratarata dari 4 zat gizi (MGP4), 10 zat gizi (MGP10), dan 14 zat gizi (MGP14). Tabel 5 menunjukkan rata-rata nilai MGP4 anak usia 2-6 tahun sebesar 75.1 17 .9. Sebagian besar (34.6\%) anak usia 2-6 tahun masuk ke dalam kategori MGP4 yang baik. Rata-rata nilai MGP10 anak usia 2-6 tahun sebesar $62.2 \pm 18.2$. Se-

Tabel 4. Persentase Rata-rata Tingkat Kecukupan Zat Gizi, Standar Deviasi dan Median menurut Jenis Kelamin, dan Kelompok Usia

\begin{tabular}{|c|c|c|c|c|c|}
\hline \multirow{3}{*}{ Zat Gizi } & \multicolumn{2}{|c|}{ Laki-laki } & \multicolumn{2}{|c|}{ Perempuan } & \multirow{3}{*}{ Total } \\
\hline & $2-3$ tahun & 4-6 tahun & $2-3$ tahun & 4-6 tahun & \\
\hline & \multicolumn{4}{|c|}{ Mean $\pm S D(m e d)$} & \\
\hline Energi (kkal) & $90.8 \pm 26.5(11.1)$ & $80.1 \pm 23.0(9.1)$ & $91.1 \pm 26.4(11.1)$ & $81.7 \pm 23.5(9.2)$ & $84.4 \pm 24.4(9.7)$ \\
\hline Protein (g) & $138.5 \pm 42.2(17.5)$ & $140.2 \pm 40.1(17.6)$ & $138.6 \pm 42.5(16.8)$ & $141.6 \pm 40.8(17.0)$ & $140.1 \pm 41.1(17.3)$ \\
\hline Lemak (g) & $56.7 \pm 21.5(2.9)$ & $55.5 \pm 19.7$ (3.0) & $56.9 \pm 21.1(3.0)$ & $57.1 \pm 20.0(3.0)$ & $56.5 \pm 20.4(3.0)$ \\
\hline Karbohidrat (g) & $109.6 \pm 39.5(5.8)$ & $88.7 \pm 31.5(3.6)$ & $109.8 \pm 39.4(5.7)$ & $90.8 \pm 32.2(3.7)$ & $96.8 \pm 34.8(4.2)$ \\
\hline Air $(m L)$ & $76.7 \pm 24.9(7.6)$ & $68.3 \pm 20.0(6.8)$ & $74.9 \pm 23.8(7.4)$ & $68.5 \pm 20.3(6.4)$ & $71.0 \pm 21.7(7.3)$ \\
\hline Vitamin A ( $\mu g)$ & $76.0 \pm 41.3(0.0)$ & $58.6 \pm 35.0(0.0)$ & $71.8 \pm 39.0(0.0)$ & $58.0 \pm 34.4(0.0)$ & $63.8 \pm 36.7(0.0)$ \\
\hline Vitamin B1 (mg) & $96.6 \pm 45.7(6.8)$ & $87.8 \pm 44.6(5.5)$ & $98.4 \pm 46.4(6.7)$ & $86.7 \pm 44.4(5.1)$ & $90.8 \pm 45.1(6.0)$ \\
\hline Vitamin B9 $(\mu \mathrm{g})$ & $54.4 \pm 21.5(4.7)$ & $38.4 \pm 13.7$ (3.8) & $53.3 \pm 21.3(4.7)$ & $37.8 \pm 13.8(3.6)$ & $43.7 \pm 16.9(4.0)$ \\
\hline Vitamin B12 ( $\mu \mathrm{g})$ & $143.2 \pm 69.5(0.0)$ & $117.4 \pm 58.0(0.0)$ & $141.3 \pm 69.5(0.0)$ & $112.6 \pm 56.0(0.0)$ & $124.6 \pm 61.7(0.0)$ \\
\hline Vitamin C (mg) & $47.4 \pm 30.8(0.0)$ & $34.1 \pm 23.5(0.0)$ & $46.6 \pm 31.0(0.0)$ & $33.0 \pm 22.5(0.0)$ & $38.3 \pm 26.0(0.0)$ \\
\hline Kalsium (mg) & $66.7 \pm 40.0(2.3)$ & $43.3 \pm 27.0(1.7)$ & $64.3 \pm 39.3(2.3)$ & $42.9 \pm 27.0(1.7)$ & $51.0 \pm 32.0(2.0)$ \\
\hline Fosfor (mg) & $85.5 \pm 31.3(8.0)$ & $89.8 \pm 32.0(8.8)$ & $83.1 \pm 31.5(7.4)$ & $87.2 \pm 30.9(8.3)$ & $87.0 \pm 31.4(8.4)$ \\
\hline Besi (mg) & $108.3 \pm 49.9(10.9)$ & $109.4 \pm 48.4(11.1)$ & $104.5 \pm 48.7(10.1)$ & $108.9 \pm 48.6(10.3)$ & $108.2 \pm 48.8(10.7)$ \\
\hline Seng (mg) & $92.0 \pm 31.5(10.0)$ & $72.4 \pm 21.4(8.2)$ & $89.2 \pm 30.8(10.0)$ & $70.8 \pm 21.1(8.0)$ & $78.3 \pm 25.2(8.9)$ \\
\hline
\end{tabular}

Tabel 5. Rata-Rata Mutu Gizi Konsumsi Pangan Anak Usia 2-6 Tahun menurut Jenis Kelamin dan Kategori Mutu Gizi Konsumsi Pangan

\begin{tabular}{|c|c|c|c|}
\hline \multirow{2}{*}{ Kategori MGP } & Laki-laki & Perempuan & \multirow{2}{*}{ Total } \\
\hline & \multicolumn{2}{|c|}{ Mean $\pm \mathrm{SD}($ med $) \%$} & \\
\hline \multicolumn{4}{|l|}{ MGP4: } \\
\hline Sangat kurang & $44.0 \pm 8.4(45.9) 15.9^{a}$ & $43.9 \pm 8.2(45.8) 14.9^{b}$ & $44.0 \pm 8.3(45.9) 15.4$ \\
\hline Kurang & $63.3 \pm 4.3(63.8) 20.4^{\mathrm{a}}$ & $63.3 \pm 4.3(63.8) 19.9^{\mathrm{b}}$ & $63.3 \pm 4.3(63.8) 20.2$ \\
\hline Cukup & $77.8 \pm 4.3(78.0) 30.1^{\mathrm{a}}$ & $77.8 \pm 4.3(77.9) 29.7^{b}$ & $77.8 \pm 4.3$ (77.9) 29.9 \\
\hline Baik & $93.5 \pm 5.0(93.3) 33.6^{\mathrm{a}}$ & $93.4 \pm 5.0(93.3) 35.6^{\mathrm{b}}$ & $93.4 \pm 5.0(93.3) 34.6$ \\
\hline Total & $74.8 \pm 18.0(77.4) 100.0^{a}$ & $75.4 \pm 17.8(78.0) 100.0^{b}$ & $75.1 \pm 17.9$ (77.7) 100.0 \\
\hline \multicolumn{4}{|l|}{ MGP10: } \\
\hline Sangat kurang & $42.0 \pm 9.4(43.8) 34.3^{a}$ & $42.3 \pm 9.4(44.3) 35.5^{b}$ & $42.2 \pm 9.4(44.0) 34.9$ \\
\hline Kurang & $62.6 \pm 4.3(62.7) 29.8^{\mathrm{a}}$ & $62.7 \pm 4.2(62.8) 29.4^{\mathrm{b}}$ & $62.7 \pm 4.2(62.7) 29.6$ \\
\hline Cukup & $76.8 \pm 4.2(76.4) 24.6^{a}$ & $76.9 \pm 4.2(76.6) 24.0^{b}$ & $76.8 \pm 4.2(76.5) 24.3$ \\
\hline Baik & $91.5 \pm 4.4(91.0) 11.3^{a}$ & $91.3 \pm 4.5(90.5) 11.1^{\mathrm{b}}$ & $91.4 \pm 4.4(90.7) 11.2$ \\
\hline Total & $62.3 \pm 18.2(63.0) 100.0^{a}$ & $62.0 \pm 18.2(62.7) 100.0^{\mathrm{b}}$ & $62.2 \pm 18.2(62.9) 100.0$ \\
\hline \multicolumn{4}{|l|}{ MGP14: } \\
\hline $\begin{array}{l}\text { Sangat kurang } \\
\text { Kurang }\end{array}$ & $\begin{array}{l}43.1 \pm 8.9(45.0) 32.7^{\mathrm{a}} \\
62.5 \pm 4.3(62.5) 32.3^{\mathrm{a}}\end{array}$ & $62.4 \pm 4.3(62.4) 31.9^{b}$ & $62.5+4.3(62.4) 32.1$ \\
\hline & & $768+4.3(76.4) 24,1 b$ & \\
\hline Cukup & $76.8 \pm 4.3(76.4) 24.5^{a}$ & $76.8 \pm 4.3(76.4) 24.1^{\mathrm{D}}$ & $76.8 \pm 4.2(76.4) 24.3$ \\
\hline Baik & $90.8 \pm 4.0(90.3) 10.5^{\mathrm{a}}$ & $90.7 \pm 4.0(90.1) 10.0^{b}$ & $90.8 \pm 4.0(90.2) 10.2$ \\
\hline Total & $62.6 \pm 17.2(63.0) 100.0^{a}$ & $62.2 \pm 17.1(62.4) 100.0^{\mathrm{b}}$ & $62.4 \pm 17.1(62.7) 100.0$ \\
\hline
\end{tabular}


bagian besar subjek (34.9\%) termasuk dalam kategori MGP10 sangat kurang. Rata-rata nilai MGP14 subjek sebesar 62.4ะ17.1. Berdasarkan kategori MGP diketahui bahwa sebagian besar anak usia 2-6 tahun masuk pada kategori MGP14 sangat kurang dengan persentase sebesar $33.3 \%$. Hasil ini sejalan dengan penelitian yang pernah dilakukan oleh Hardinsyah et al. (2000) tentang penilaian mutu gizi konsumsi pangan pada ibu hamil dan anak batita. Penelitian yang menggunakan sistem skor makanan tersebut menunjukkan bahwa mutu gizi konsumsi pangan pada anak batita juga relatif masih rendah.

Rata-rata total skor PPH pada anak laki-laki dan perempuan usia $2-6$ tahun sebesar $67.1 \pm 12.9$, rata-rata total skor PPH pada subjek laki-laki sebesar 67.0 \pm 12.9 , dan rata-rata total skor PPH pada subjek perempuan sebesar 67.3 \pm 12.8 (Tabel 6). Hasil tersebut menunjukkan bahwa skor PPH pada anak perempuan lebih tinggi dibandingkan dengan lakilaki. Berdasarkan hasil penelitian ini dapat diketahui bahwa konsumsi pangan individu anak usia 2-6 tahun belum beragam yang ditandai dengan skor PPH kurang dari 100. Hasil penelitian ini sejalan dengan penelitian yang dilakukan oleh Tejasari (2003) yang dilakukan di daerah rawan gizi dimana nilai skor $\mathrm{PPH}$ relatif masih rendah. Penelitian Zhang $\mathrm{H}$ et al. (2008) yang dilakukan di perdesaan dan perkotaan di Guangxi, Cina menunjukkan skor PPH di atas 70. Hasil ini menunjukkan bahwa skor PPH pada penelitian ini lebih rendah dibandingkan penelitian Zhang $\mathrm{H}$ et al. (2008) di China. Rendahnya nilai PPH ini diduga dikarenakan kurangnya konsumsi pangan yang beragam dan mencukupi dari sembilan kelompok pangan tersebut.

\section{Hubungan antara Tingkat kecukupan Zat Gizi dengan Skor PPH dan Mutu Gizi Pangan}

Uji korelasi Rank Spearman menunjukkan terdapat hubungan yang signifikan antara ting- kat kecukupan energi dengan skor PPH $(p<0.05)$; $r=0.592)$, MGP4 ( $r=0.930)$, MGP10 $(r=0.685)$, dan MGP14 ( $r=0.685)$. Tingkat kecukupan energi meningkat seiring dengan semakin baiknya skor PPH dan MGP. Berdasarkan hasil uji korelasi Rank Spearman menunjukkan adanya hubungan yang signifikan antara skor PPH dengan MGP4 $(p<0.05 ; r=0.621)$, MGP10 ( $r=0.578)$, dan MGP14 ( $r=0.605)$. Hasil penelitian ini menunjukkan adanya hubungan yang bernilai positif dan signifikan antara tingkat kecukupan zat gizi dengan skor PPH dan mutu gizi konsumsi pangan $(p<0.05)$. Dengan demikian dapat dikatakan bahwa semakin tinggi tingkat kecukupan zat gizi maka skor PPH dan MGP semakin meningkat. Menurut Hardinsyah (2007) keragaman konsumsi pangan dapat menggambarkan mutu gizi konsumsi pangan. Hasil penelitian ini sejalan dengan penelitian Steyn et al. (2007) yang dilakukan pada anak usia 1-8 tahun di Afrika Selatan. Penelitian tersebut menunjukkan adanya korelasi antara skor keragaman pangan dengan tingkat kecukupan zat gizi. Penelitian ini juga sejalan dengan penelitian yang dilakukan oleh Hardinsyah et al. (2000) yang menggunakan data survei konsumsi gizi (SKG) 1997. Penelitian tersebut menunjukkan semakin tinggi skor keragaman konsumsi pangan semakin tinggi pula mutu gizi konsumsi pangan.

\section{KESIMPULAN}

Hasil penelitian menunjukkan bahwa ada hubungan yang signifikan antara skor PPH dengan MGP4, MGP10, dan MGP14 ( $<<0.05)$. Korelasi antara skor PPH dan masing-masing MGP menunjukkan hasil validitas yang sedang $(r=0.578-0.621)$.

Sistem penilaian PPH individu perlu disempurnakan agar dapat diterapkan untuk menilai mutu gizi konsumsi pangan (MGP). Salah satu cara yang dapat digunakan untuk menyempurnakan sistem tersebut

Tabel 6. Rata-Rata Skor PPH Anak 2-6 Tahun Menurut Jenis Kelamin dan Kelompok Pangan

\begin{tabular}{lccc}
\hline & \multicolumn{1}{c}{ Laki-laki } & Perempuan & Laki-laki dan Perempuan \\
\cline { 2 - 4 } Kelompok Pangan & \multicolumn{3}{c}{$\begin{array}{c}\text { Skor PPH } \\
\text { mean } \pm \text { SD }(\text { med }) \\
\text { min-max }\end{array}$} \\
\cline { 2 - 4 } & $20.5 \pm 5.4(22.8)^{\mathrm{a}} 1.1-25.0$ & $20.7 \pm 5.3(23.3)^{\mathrm{b}} 0.7-25.0$ & $20.6 \pm 5.4(23.1) 0.7-25.0$ \\
\hline Padi-padian & $2.1 \pm 0.6(2.5)^{\mathrm{a}} 0.1-2.5$ & $2.1 \pm 0.6(2.5)^{\mathrm{b}} 0.1-2.5$ & $2.1 \pm 0.6(2.5) 0.1-2.5$ \\
Umbi-umbian & $20.2 \pm 6.0(24.0)^{\mathrm{a}} 0.2-24.0$ & $20.1 \pm 6.1(24.0)^{\mathrm{b}} 0.0-24.0$ & $20.1 \pm 6.1(24.0) 0.0-24.0$ \\
Pangan hewani & $3.8 \pm 1.3(4.4)^{\mathrm{a}} 0.9-5.0$ & $4.0 \pm 1.3(5.0)^{\mathrm{b}} 0.7-5.0$ & $3.9 \pm 1.3(4.9) 0.7-5.0$ \\
Minyak dan lemak & $0.9 \pm 0.2(1.0)^{\mathrm{a}} 0.2-1.0$ & $0.9 \pm 0.2(1.0)^{\mathrm{b}} 0.1-1.0$ & $0.9 \pm 0.2(1.0) 0.1-1.0$ \\
Buah/biji berminyak & $9.2 \pm 1.8(10.0)^{\mathrm{a}} 0.8-10.0$ & $9.2 \pm 1.9(10.0)^{\mathrm{b}} 0.4-10.0$ & $9.2 \pm 1.9(10.0) 0.4-10.0$ \\
Kacang-kacangan & $2.3 \pm 0.5(2.5)^{\mathrm{a}} 0.0-2.5$ & $2.3 \pm 0.4(2.5)^{\mathrm{b}} 0.0-2.5$ & $2.3 \pm 0.5(2.5) 0.0-2.5$ \\
Gula & $8.0 \pm 8.8(4.1)^{\mathrm{a}} 0.0-30.0$ & $8.0 \pm 8.8(4.0)^{\mathrm{b}} 0.1-30.0$ & $8.0 \pm 8.8(4.0) 0.0-30.0$ \\
Sayur dan buah & $0.0 \pm 0.0(0.00)^{\mathrm{a}} 0.0-0.0$ & $0.0 \pm 0.0(0.0)^{\mathrm{b}} 0.0-0.0$ & $0.0 \pm 0.0(0.0) 0.0-0.0$ \\
Lainnya & $67.0 \pm 12.9(47.5)^{\mathrm{a}} 10.2-91.5$ & $67.3 \pm 12.8(47.8)^{\mathrm{b}} 10.4-93.8$ & $67.1 \pm 12.9(47.7) 10.23-93.8$ \\
\hline Total & &
\end{tabular}

Keterangan: Tanda yang berbeda $(a, b)$ menunjukkan hasil uji beda yang signifikan 
yaitu dengan perbaikan pengelompokan pangan dan skoring sistem.

\section{UCAPAN TERIMA KASIH}

Ucapan terima kasih penulis sampaikan kepada Badan Penelitian dan Pengembangan Kesehatan (Balitbangkes) Kementerian Kesehatan yang telah memberikan izin kepada penulis untuk menggunakan data Riskesdas 2010.

\section{DAFTAR PUSTAKA}

Apriani S \& Baliwati YF. 2011. Faktor-faktor yang berpengaruh terhadap konsumsi pangan sumber karbohidrat di perdesaan dan perkotaan. JGP, 6(3), 200-207.

Hardinsyah. 1996. Measurement and Determinants of Food Diversity: Implication for Indonesia's Food and Nutrition Policy [Disertation]. Faculty of Medicine, University of Queensland, Brisbane.

Hardinsyah. 2007. Review faktor determinan keragaman konsumsi pangan. JGP, 2(2), 55-74.

Hardinsyah, Kusno SR, \& Khomsan A. 2000. Ukuran sederhana diversifikasi konsumsi pangan untuk identifikasi keluarga rawan pangan. Media Gizi dan Keluarga, XXIV(1), 15-20.

Hardinsyah, Mailoa M, \& Herawati N. 2000. Cara sederhana penilaian mutu gizi makanan ibu hamil dan anak balita. Media Gizi dan Keluarga, XXIV(1), 98-103.

Hardinsyah et al. 2001. Pengembangan konsumsi pa- ngan dengan pendekatan pola pangan harapan. PSKPG-IPB dan Pusat Pengembangan Konsumsi Pangan Badan Bimas Ketahanan Pangan (BBKP), Departemen Pertanian, Bogor.

Mahan K \& Escott-Stump. 2004. Food, Nutrition, and Diet Therapy. WB Saunders Company, USA.

Mauludyani AVR, Martianto D, \& Baliwati Y. 2008. Pola konsumsi dan permintaan pangan pokok berdasarkan analisis data Susenas 2005. JGP, 3(2), 101-117.

[Kemenkes RI] Kementerian Kesehatan Republik Indonesia. 2011. Laporan Riset Kesehatan Dasar tahun 2010. Kementrian Kesehatan, Jakarta.

Riyadi H \& Sukandar D. 2009. Asupan Gizi Anak Balita Peserta Posyandu. JGP, 4(1), 41-50.

Steyn NP, Nel JH, Nantel G, Kennedy J, \& Labadarios D. 2006. Food variety and dietary diversity scores in children: are they good indicators of dietary adequacy?. Public Health Nutrition, 9(5), 644-650.doi: 10.1079/PHN2005912.

Tejasari. 2003. Diversifikasi konsumsi pangan berdasarkan pendekatan pola pangan harapan (PPH) di daerah rawan gizi. Media Gizi \& Keluarga, 27(1), 46-53.

Willet WC \& McCullough ML. 2008. Dietary pattern analysis for the evaluation of dietary guidelines. Asia Pac J Clin Nutr, 17(S1), 75-78.

Zhang H, Chen Z, Pen Q, \& Lin X. 2008. Evaluation of dietary pattern by the Desirable Dietary Pattern (DDP) Score in urban and rural population in Guangxi, China. The Journal of the Federation of American Societies for Experimental Biology, 22, (1083.2). 